\title{
Hydration studies of calcium sulfoaluminate cements blended with fly ash
}

\author{
M. García-Maté a , A.G. De la Torre a , L. León-Reina ${ }^{\text {b }}$, M.A.G. Aranda a,c ${ }^{\text {, I. Santacruz }}{ }^{\text {a,* }}$ \\ a Departamento de Química Inorgánica, Cristalografía y Mineralogía, Universidad de Málaga, 29071 Málaga, Spain \\ b Servicios Centrales de Apoyo a la Investigación, Universidad de Málaga, 29071 Málaga, Spain \\ c CELLS-Alba synchrotron, Carretera BP 1413, Km. 3.3, E-08290 Cerdanyola, Barcelona, Spain
}

\section{A R T I C L E I N F O}

\section{Article history:}

Received 11 February 2013

Accepted 4 July 2013

Available online $\mathrm{xxxx}$

\section{Keywords:}

$\mathrm{X}$-Ray diffraction analysis

Hydration (A)

Compressive strength $(C)$

Sulfoaluminate (D)

Blended cement (D)

\begin{abstract}
A B S T R A C T
The main objective of this work is to study the hydration and properties of calcium sulfoaluminate cement pastes blended with fly ash (FA) and the corresponding mortars at different hydration ages. Laboratory X-ray powder diffraction, rheological studies, thermal analysis, porosimetry and compressive strength measurements were performed. The analysis of the diffraction data by Rietveld method allowed quantifying crystalline phases and overall amorphous contents. The studied parameters were: i) FA content, 0,15 and $30 \mathrm{wt}$ \%; and ii) water addition, water-to-CSA mass ratio ( $\mathrm{w} / \mathrm{CSA}=0.50$ and 0.65$)$, and water-to-binder mass ratio $(\mathrm{w} / \mathrm{b}=0.50)$. Finally, compressive strengths after 6 months of 0 and $15 \mathrm{wt} . \% \mathrm{FA}[\mathrm{w} / \mathrm{CSA}=0.50]$ mortars were similar: $73 \pm 2$ and $72 \pm 3 \mathrm{MPa}$, respectively. This is justified by the filler effect of the FA as no strong evidences of reactivity of FA with CSA were observed. These results support the partial substitution of CSA cements with FA with the economic and environmental benefits.
\end{abstract}

(c) 2013 Elsevier Ltd. All rights reserved.

\section{Introduction}

Calcium sulfoaluminate (CSA) cements are receiving increasing attention since their manufacture produces much less $\mathrm{CO}_{2}$ than ordinary Portland cement (OPC) [1-5]. In addition, they show interesting properties such as high early-age strengths [6-8], short setting times, impermeability $[9,10]$, sulfate and chloride corrosion resistance and low alkalinity. The main uses of these CSA cements, or blended with Portland cements, are for quick repairs and pre-cast products or floor concrete applications [11]. All these properties are related to the resulting hydration phases at the first hours of hydration. Early hydration of CSA cements [12,13] gives ettringite also named as $\mathrm{AFt}\left(\mathrm{C}_{6} \mathrm{AS}_{3} \mathrm{H}_{32}\right)$, and monosulfate also known as AFm $\left(\mathrm{C}_{4} \mathrm{ASH}_{12}\right)$ [14], as main crystalline phases, depending mainly upon the sulfate availability. CSA binders may show variable compositions, but all of them contain ye'elimite, also called Klein's salt or tetracalcium trialuminate sulfate $\left(\mathrm{C}_{4} \mathrm{~A}_{3} \mathrm{~S}\right)[1,15]$. Ye'elimite synthesis produces only a third part of the $\mathrm{CO}_{2}$ released by the production of alite content in OPCs [16]. Moreover, its clinkering temperature $\left(\sim 1250{ }^{\circ} \mathrm{C}\right)$ is lower than that for OPC clinkers, consequently there are environmental benefits due to fuel savings. Ye'elimite-containing clinkers are easier to be ground than OPC clinkers, and waste materials or industrial byproducts can be used in the kiln feed as raw material.

Another environmental strategy for reducing the negative impact of the cement industry is the partial substitution of cement by by-products materials (such as fly ash or slag) also known as supplementary

\footnotetext{
* Corresponding author. Tel.: + 34 952131992; fax: + 34952132000

E-mail address: isantacruz@uma.es (I. Santacruz).
}

cementitious materials (SCMs) [17-19]. The environmental benefits of the use of waste materials are two folds, lower $\mathrm{CO}_{2}$ emissions because of the clinker reduction, and the valorization of a "useless" product. Furthermore, the addition of SCMs to cement may give the possibility of the modification of their properties [20] and mortars/concretes prepared from blends, such as decreased hydration heat, improved workability of fresh mortar/concrete mix, improved chemical resistance, ultimate strength increase, and improvement of other engineering properties of concrete [21]. However, the extent of replacement is limited by the following problems: reduced early strength, limited amounts of reactive SCMs and limited replacement by non-reactive SCMs without compromising final strength. In any case, it is essential to control/understand the hydration process $[14,22,23]$ without or with SCMs. The effect of the addition of by-products to OPC pastes has already been well described in literature [24,25]. However, for CSA cements, it is needed to understand all parameters involved in the CSA-SCMs hydration, and the key roles of water and SCMs contents. The $\mathrm{w} / \mathrm{c}$ ratio required for full CSA hydration is higher than that for an OPC [26]. The specific water demand for complete hydration will depend on CSA phase assemblage (mainly ye'elimite and belite contents). For instance, pure ye'elimite reacting with the stoichiometric amount of anhydrite to yield ettringite requires a $0.78 \mathrm{w} / \mathrm{c}$ mass ratio [14,27]. This means that a CSA with $\sim 50$ wt.\% of ye'elimite would need a w/CSA ratio of 0.5 , which may yield pastes with larger pore diameters than OPC pastes. Moreover, high w/c ratios may involve severe expansion [28] also resulting in poor final strengths; however, lower initial particle sizes or the use of additives may reduce some of these undesirable properties $[26,29,30]$. 
The objective of this work is to study the hydration and properties of blended CSA-FA cement pastes, including phase assemblage evolution with hydration time, workability of the pastes at very early ages and porosity. Finally, the mechanical properties of the corresponding mortars have been correlated to those variables and the role of FA addition has been discussed. The findings of this study may be also of interest to understand other ye'elimite-containing cements like sulfobelite cements.

\section{Materials and methods}

\subsection{Materials}

\subsubsection{Anhydrous cement preparation}

Calcium sulfoaluminate clinker (CS10), industrially produced in China and marketed in Europe by BELITH S.P.R.L. (Belgium), was used as raw material. Calcium sulfoaluminate cement was prepared by mixing clinker with 25 wt.\% of commercial micron natural gypsum also marketed by BELITH S.P.R.L. (Belgium), hereafter CS10-25. As supplementary cementitious material, a class F fly ash (FA), ASTM C618, from the power station of Lada (Spain) [31] was added to the cement powder at different concentrations $(0,15$ and $30 \mathrm{wt} . \%$, labeled hereafter OFA, 15FA and 30FA, respectively). Table 1 shows the elemental analysis of the three raw materials (CS10, gypsum and fly ash) determined by X-ray fluorescence (XRF) in a Magic X spectrometer (PANalytical, Almelo, The Netherlands) using the calibration curve of silica-alumina materials. The Blaine fineness values determined for CS10 and gypsum were 480 and $500 \mathrm{~m}^{2} / \mathrm{kg}$, respectively.

\subsubsection{Cement pastes preparation}

Cement pastes were prepared with distilled water at w/CSA ratios of 0.50 and 0.65 and $\mathrm{w} /$ binder $(\mathrm{w} / \mathrm{b}$ ) of 0.50 . Table 2 includes, in the first column in italics, the equivalence between $w / C S A$ and $w / b$ for every paste. Pastes were mechanical stirred with helices according to EN196-3:2005 standard procedure. These cement pastes were placed over a plastic sample holder covered with plastic foil and cured at $20 \pm 1{ }^{\circ} \mathrm{C}$ and $99 \%$ relative humidity ( $\mathrm{RH}$ ) for 3, 7, 28 and 180 days. After the given time, pastes were divided into two fractions to perform further characterization, detailed below.

\subsubsection{Stopping cements hydration}

One fraction of the pastes was milled to fine powder in an agate mortar prior to stopping hydration. The stopping procedure consisted on filtration in a Whatman system (90 $\mathrm{mm}$ diameter Whatman filter with a pore size of $2.5 \mu \mathrm{m}$ and a Teflon support) with acetone (Prolabo

Table 1

X-ray fluorescence analysis for the three raw materials (clinker, gypsum and fly ash) and RQPA for cement and fly ash anhydrous powders.

\begin{tabular}{|c|c|c|c|c|c|c|}
\hline \multicolumn{4}{|l|}{$\mathrm{XRF}$} & \multicolumn{3}{|l|}{ RQPA } \\
\hline & $\begin{array}{l}\text { CS10 } \\
\text { (wt.\%) }\end{array}$ & $\begin{array}{l}\text { Gypsum } \\
\text { (wt.\%) }\end{array}$ & $\begin{array}{l}\text { Fly Ash }^{\mathrm{a}} \\
\text { (wt.\%) }\end{array}$ & & $\begin{array}{l}\text { CS10-25 } \\
\text { (wt.\%) }\end{array}$ & $\begin{array}{l}\text { Fly Ash } \\
\text { (wt.\%) }\end{array}$ \\
\hline $\mathrm{Al}_{2} \mathrm{O}_{3}$ & 33.80 & 0.37 & 26.40 & $\mathrm{C}_{4} \mathrm{~A}_{3} \mathrm{~S}$ & 40.3 & - \\
\hline $\mathrm{CaO}$ & 41.97 & 31.20 & 4.53 & $\mathrm{CSH}_{2}^{-}$ & 26.1 & - \\
\hline $\mathrm{Fe}_{2} \mathrm{O}_{3}$ & 2.37 & 0.12 & 7.45 & $\beta-C_{2} S$ & 9.4 & - \\
\hline $\mathrm{K}_{2} \mathrm{O}$ & 0.25 & 0.054 & 3.56 & $\mathrm{CaTiO}_{3}$ & 5.7 & - \\
\hline $\mathrm{SiO}_{2}$ & 8.20 & 0.73 & 52.70 & $\mathrm{MgO}$ & 1.2 & - \\
\hline $\mathrm{MgO}$ & 2.73 & 0.098 & 1.93 & Akermanite & 1.2 & - \\
\hline $\mathrm{P}_{2} \mathrm{O}_{5}$ & 0.13 & 0.44 & 0.28 & $\mathrm{C}_{4} \mathrm{AF}$ & 0.7 & - \\
\hline $\mathrm{TiO}_{2}$ & 1.50 & - & 0.96 & Mullite & - & 8.4 \\
\hline $\mathrm{SO}_{3}$ & 8.80 & 42.40 & - & Quartz & - & 5.3 \\
\hline $\mathrm{SrO}$ & 0.15 & 2.38 & - & Hematites & - & 0.4 \\
\hline $\mathrm{B}_{2} \mathrm{O}_{3}$ & - & - & - & Magnesium-Ferrite & - & 0.5 \\
\hline $\mathrm{Cr}_{2} \mathrm{O}_{3}$ & 0.017 & - & - & Lime & - & 0.2 \\
\hline $\mathrm{MnO}$ & 0.011 & - & 0.05 & Periclase & - & 0.2 \\
\hline $\mathrm{ZrO}_{2}$ & 0.070 & - & - & $\mathrm{ACn}$ & 15.4 & 85.0 \\
\hline $\mathrm{Na}_{2} \mathrm{O}$ & $<0.08$ & 0.20 & 0.53 & - & - & - \\
\hline LoI & - & 22.00 & 1.60 & SUM & 100.0 & 100.0 \\
\hline
\end{tabular}

a Data from literature [31].
S.A.) twice and finally with diethyl ether (Prolabo S.A.). The stoppedhydration samples were stored in a desiccator to avoid further hydration and any possible carbonation/alteration [32].

\subsection{Characterization}

\subsubsection{Rheological behavior}

Rheological measurements of the pastes were carried out using a viscometer (Model VT550, Thermo Haake, Karlsruhe, Germany) with a serrated coaxial cylinder sensor, SV2P, provided with a solvent trap to reduce evaporation. Flow curves were obtained with controlled rate (CR) measurements. Ramp times of $6 \mathrm{~s}$ were recorded in the shear rate range between 2 and $100 \mathrm{~s}^{-1}$, for a total of 12 ramps. A further decrease from 100 to $2 \mathrm{~s}^{-1}$ shear rate was performed by following the same ramp times. Before starting the rheological measurement, the pastes were pre-sheared for $30 \mathrm{~s}$ at $100 \mathrm{~s}^{-1}$ and held at $0 \mathrm{~s}^{-1}$ for $5 \mathrm{~s}$.

\subsubsection{Laboratory X-ray powder diffraction ( $L X R P D)$}

LXRPD studies were performed on grounded anhydrous materials and pastes (after stopping hydration) at every age. Patterns were recorded on an X'Pert MPD PRO diffractometer (PANalytical) using strictly monochromatic $\mathrm{CuK} \alpha_{1}$ radiation $(\lambda=1.54059 \AA)$ [ $\mathrm{Ge}(111)$ primary monochromator] and working in reflection geometry $(\theta / 2 \theta)$. The X-ray tube worked at $45 \mathrm{kV}$ and $40 \mathrm{~mA}$. The optics configuration was a fixed divergence slit $\left(1 / 2^{\circ}\right)$, a fixed incident antiscatter slit $\left(1^{\circ}\right)$, a fixed diffracted anti-scatter slit $\left(1 / 2^{\circ}\right)$ and X'Celerator RTMS (Real Time Multiple Strip) detector, working in scanning mode with maximum active length. Data were collected from $5^{\circ}$ to $70^{\circ}(2 \theta)$ during $\sim 2 \mathrm{~h}$. The samples were rotated during data collection at $16 \mathrm{rpm}$ in order to enhance particle statistics.

$\mathrm{G}$-factor approach, which is explained below, requires the recording of an external standard pattern collected in identical diffractometer configuration/conditions and as close in time as possible to the measurements to determine a diffractometer constant (G-factor). Diffractometer experimental set up for standards was the same as detailed above except for the spinning of the sample. The methodology detailed elsewhere [33] was followed by using a polished polycrystalline quartz rock as secondary standard placed on the diffractometer in the very same orientation. The suitability of this quartz-rock was tested against NIST standard reference material SRM-676a $\left(\alpha-\mathrm{Al}_{2} \mathrm{O}_{3}\right)$ [34].

\subsubsection{LXRPD data analysis}

LXRPD patterns of anhydrous powders, stopped-hydration pastes and external standard were analyzed by the Rietveld method as implemented in the GSAS software package [35] to extract the quantitative phase analyses (QPA). The refined overall parameters were cell parameters, zero-shift error, peak shape parameters, and phase scales. Peak shapes were fitted by using the pseudo-Voigt function [36] corrected for axial divergence [37]. The simplest approach to derive the phase content from the Rietveld refined scale factor is by the approximation that the sample is only composed of crystalline phases with known structures (normalization to full crystalline content method). However, the G-factor approach was used to obtain a full mineralogical phase assemblage which includes amorphous contents. This approach quantifies not only amorphous/sub-cooled phases but also misfitting problems of the analyzed crystalline phases and any crystalline phase non-included in the Rietveld control file. Hereafter, this derived value will be called Amorphous and Crystalline not-quantified, ACn [38]. The absolute weight fractions for all crystalline phases are derived using the G-factor approach from their refined phase fractions, and ACn contents are obtained from the difference of the total crystalline phases to 100 , knowing the mass attenuation coefficients of the samples $[39,40]$.

\subsubsection{Mercury intrusion porosimetry}

The porosity of selected pastes was measured through mercury porosimetry (MP) using a Quantachrome (Autoscan 33, Boynton Beach, 
Table 2

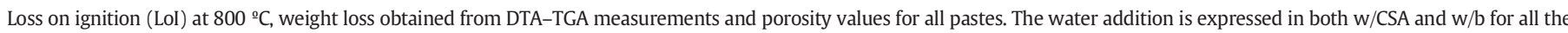
pastes.

\begin{tabular}{|c|c|c|c|c|c|c|c|}
\hline Paste & $\begin{array}{l}\text { Hydration } \\
\text { time/day }\end{array}$ & $\begin{array}{l}\text { Theoretical } \\
\text { total weight } \\
\text { loss/\% }\end{array}$ & $\begin{array}{l}\text { LoI / \% } \\
\text { Non-stop } \\
\text { hydration }\end{array}$ & $\begin{array}{l}\text { Weight } \\
\text { loss- } 600{ }^{\circ} \mathrm{C} / \% \\
\text { (stop hydration) }\end{array}$ & $\begin{array}{l}\text { Expected weight } \\
\text { loss- } 600{ }^{\circ} \mathrm{C} / \%\end{array}$ & $\begin{array}{l}\text { Weight loss- } \\
600-1000{ }^{\circ} \mathrm{C} / \% \\
\text { (stop hydration) }\end{array}$ & $\begin{array}{l}\text { Open porosity } \\
\text { (vol.\%) }\end{array}$ \\
\hline OFA & 3 & 36.79 & 37.6 & 31.0 & - & 0. & - \\
\hline $\mathrm{w} / \mathrm{CSA}=0.50$ & 7 & & 39.0 & 31.4 & - & 1.4 & 14.7 \\
\hline \multirow[t]{2}{*}{$w / b=0.50$} & 28 & & 39.8 & 31.9 & - & 2.2 & - \\
\hline & 180 & & 40.7 & 33.5 & - & 1.3 & 7.8 \\
\hline \multirow{4}{*}{$\begin{array}{l}15 \mathrm{FA} \\
\mathrm{w} / \mathrm{CSA}=0.50 \\
w / b=0.42\end{array}$} & 3 & 33.11 & 33.7 & 28.5 & 26.4 & 0.8 & - \\
\hline & 7 & & 35.8 & 29.4 & 26.7 & 1.0 & 10.2 \\
\hline & 28 & & 34.3 & 29.8 & 27.1 & 0.6 & - \\
\hline & 180 & & 35.4 & 28.6 & 28.5 & 2.5 & 6.5 \\
\hline \multirow{4}{*}{$\begin{array}{l}\text { 30FA } \\
\quad w / C S A=0.50 \\
w / b=0.35\end{array}$} & 3 & 29.00 & 29.9 & 24.4 & 21.7 & 0.9 & - \\
\hline & 7 & & - & 24.6 & 22.0 & 1.2 & 9.3 \\
\hline & 28 & & 31.8 & 25.2 & 22.3 & 1.4 & - \\
\hline & 180 & & 32.7 & 24.7 & 23.4 & 2.0 & 6.6 \\
\hline \multirow{4}{*}{$\begin{array}{l}\text { OFA } \\
\quad \mathrm{w} / \mathrm{CSA}=0.65 \\
w / b=0.65\end{array}$} & 3 & 42.56 & 42.2 & 33.4 & - & 1.0 & - \\
\hline & 7 & & 43.0 & 33.8 & - & 1.5 & 20.3 \\
\hline & 28 & & 45.0 & 35.3 & - & 1.1 & - \\
\hline & 180 & & 45.3 & 35.3 & - & 2.0 & 12.0 \\
\hline \multirow{4}{*}{$\begin{array}{l}15 \mathrm{FA} \\
\quad \mathrm{w} / \mathrm{CSA}=0.65 \\
w / b=0.55\end{array}$} & 3 & 38.60 & 37.8 & 29.8 & 28.4 & 1.0 & - \\
\hline & 7 & & 38.6 & 30.4 & 28.7 & 1.4 & 17.8 \\
\hline & 28 & & 39.6 & 31.6 & 30.0 & 1.0 & - \\
\hline & 180 & & 39.1 & 30.4 & 30.0 & 2.6 & 11.8 \\
\hline \multirow{4}{*}{$\begin{array}{l}30 \mathrm{FA} \\
\mathrm{w} / \mathrm{CSA}=0.65 \\
w / b=0.46\end{array}$} & 3 & 34.12 & 33.2 & 24.6 & 23.4 & 1.5 & - \\
\hline & 7 & & 34.1 & 25.6 & 23.7 & 1.7 & 15.2 \\
\hline & 28 & & 36.8 & 27.0 & 24.7 & 1.5 & - \\
\hline & 180 & & 37.3 & 25.4 & 24.7 & 4.7 & 14.1 \\
\hline \multirow{4}{*}{$\begin{array}{l}15 \mathrm{FA} \\
\mathrm{w} / \mathrm{b} 0.50 \\
\quad w / C S A=0.59\end{array}$} & 3 & 36.46 & 36.1 & 29.3 & 26.4 & 0.8 & - \\
\hline & 7 & & 37.5 & 29.6 & 26.7 & 1.4 & 17.4 \\
\hline & 28 & & 38.5 & 30.4 & 27.1 & 0.8 & - \\
\hline & 180 & & 41.1 & 30.6 & 28.5 & 2.8 & 11.6 \\
\hline \multirow{4}{*}{$\begin{array}{l}30 \mathrm{FA} \\
\quad \mathrm{w} / \mathrm{b}=0.50 \\
w / C S A=0.71\end{array}$} & 3 & 36.09 & 36.0 & 27.1 & 23.4 & 0.7 & - \\
\hline & 7 & & 36.8 & 26.8 & 23.7 & 0.7 & 18.8 \\
\hline & 28 & & 37.4 & 27.2 & 24.7 & 1.2 & - \\
\hline & 180 & & 39.1 & 26.6 & 24.7 & 4.6 & 13.8 \\
\hline
\end{tabular}

Florida, US) porosimeter. The assumed contact angle for data evaluation was $130^{\circ}$.

\subsubsection{Thermal analysis}

Two experiments were performed:

i) Differential thermal (DTA) and thermogravimetric (TGA) analyses were performed in a SDT-Q600 analyzer from TA instruments (New Castle, DE) for a ground fraction of all pastes after stopping hydration as described above. The temperature was varied from RT to $1000{ }^{\circ} \mathrm{C}$ at a heating rate of $10{ }^{\circ} \mathrm{C} / \mathrm{min}$. Measurements were carried out in open platinum crucibles under nitrogen flow. The weighed loss from RT to $600{ }^{\circ} \mathrm{C}$ was assumed to be water (free and chemically bounded water) and that from 600 to $1000{ }^{\circ} \mathrm{C}$ was considered as $\mathrm{CO}_{2}$. Table 2 includes these data.

ii) The loss on ignition (LoI) of a ground fraction of all pastes, without stopping hydration, was measured for a given time of hydration by heating the pastes at $800{ }^{\circ} \mathrm{C}$ for $1.5 \mathrm{~h}$ at a heating rate of $10{ }^{\circ} \mathrm{C} / \mathrm{min}$. This measurement was performed to check their adequate storage by controlling the water content of the samples. Table 2 also includes these data.

\subsubsection{Compressive strengths}

Standard mortars were prepared with water/CSA/sand or water/ binder/sand ratios of $\mathrm{X} / 1 / 3$ (X depends on $\mathrm{w} / \mathrm{CSA}$ and $\mathrm{w} / \mathrm{b}$ ratios) and mechanically homogenized according to EN196-1. Cubic samples of $30 \times 30 \times 30 \mathrm{~mm}$ for all the matrix were cast in a jolting apparatus (Model UTCM-0012, 3R, Montauban, France) with a total of 120 knocks. For a better homogenization, molds were half cast and knocked during 60 times. After that, they were fully cast and other 60 knocks were performed. The casts were cured at $20 \pm 1{ }^{\circ} \mathrm{C}$ and 99\% RH during
$24 \mathrm{~h}$. After that time, samples were demolded and cured within a water bath at $20 \pm 1{ }^{\circ} \mathrm{C}$ until measurements were performed. Compressive strengths of mortars were measured at 3, 7, 28 and 180 days and the reported values are the average of three broken cubes in a compression press (Model Autotest 200/10 W, Ibertest, Madrid, Spain). The measured compressive strength values were corrected by a factor of 1.78 to take into account the difference in the area with the standard prisms $(40 \times 40 \times 160 \mathrm{~mm})$.

\section{Results and discussion}

Table 1 shows RQPA (Rietveld Quantitative Phase Analysis) for cement (CS10-25) and fly ash anhydrous powders, including ACn. The ACn content of this CSA cement, 15 wt.\%, is slightly higher than that found for OPC cements, $\sim 10 \mathrm{wt} . \%$ [41,42], likely due to the lower clinkering temperature leading to smaller particle sizes and microstrains and defects-bearing crystals. The crystal structure descriptions for each phase were those detailed elsewhere [15], except for ye'elimite, where a reviewed orthorhombic $C_{4} A_{3} S$ has been used [43]. The ACn content in FA is 85 wt.\%, where mullite and quartz and some other crystalline minor phases (hematites, magnesium-ferrite, lime and periclase) are also present as crystalline fraction. Fig. 1a and b show the Rietveld plots for anhydrous CS10-25 cement and FA, respectively. The major peaks for each phase are labeled.

All fresh pastes were rheologically characterized in order to study the effect of the water and fly ash contents on their viscosity and hence, their flowability and water demand. All pastes showed a shear thinning behavior. Fig. $2 a$ and $b$ show the viscosity values vs. w/CSA and w/b contents, respectively, for all the pastes grouped according to their fly ash content (0,15 and $30 \mathrm{wt} . \%)$. All the values were taken from the upcurve at the shear rate of $30 \mathrm{~s}^{-1}$. Note that the viscosity of an additional 

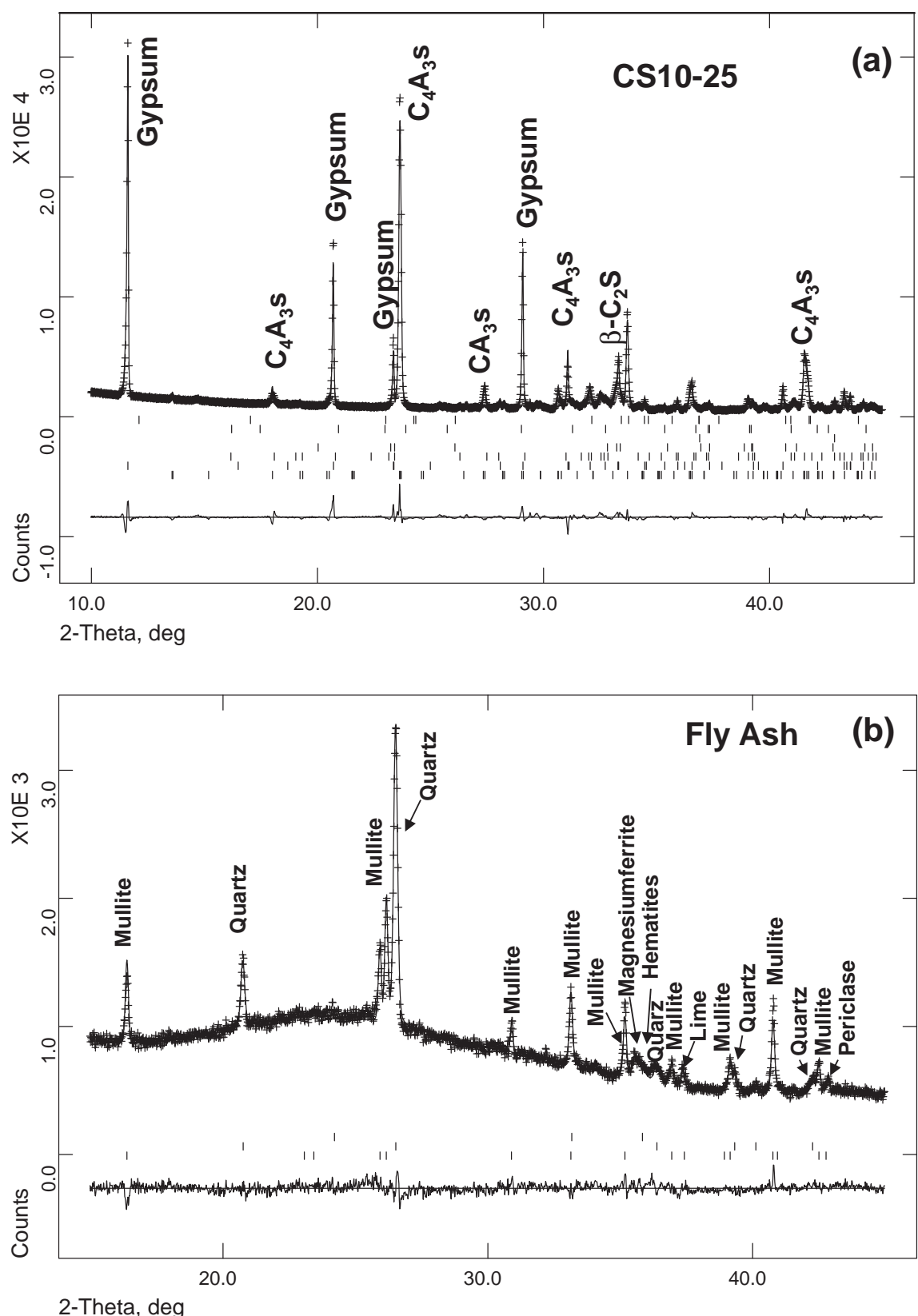

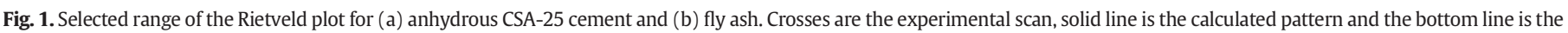
difference curve. The major peaks for each phase are labeled.

CSA-25 cement paste ( $\mathrm{w} / \mathrm{c}=0.43$ without fly ash) has been included for the sake of comparison. The viscosity increases exponentially with the solid content (lower w/CSA or w/b). For the same w/CSA ratio, Fig. 2a, viscosity values increase by increasing the fly ash content, as expected, due to the increasing of the total solid contents. At high w/CSA ratios, e.g. 0.65 , this difference in viscosity is almost negligible for pastes with 0 and 15 wt.\% of fly ash ( 0.38 and 0.44 Pa s, respectively), but this difference in viscosity becomes more important at lower water contents (higher solid contents). On the other hand, viscosity evolutions as a function of $w / b$ ratio are also presented in Fig. $2 b$. Here, for the same $w / b$ ratio, the viscosity values decrease by increasing the fly ash content (e.g. 1.38, 0.90 and $0.56 \mathrm{~Pa}$ s for pastes with $\mathrm{w} / \mathrm{b}=0.50$ and 0,15 and $30 \%$ FA, respectively). For the same viscosity value, same figure, the corresponding $\mathrm{w} / \mathrm{b}$ ratio decreases by increasing the FA content (e.g. for a viscosity of $\sim 0.9 \mathrm{~Pa} \mathrm{~s}$, the corresponding $\mathrm{w} / \mathrm{b}$ ratios for pastes with 0 , 15 and 30 wt.\% of FA are $\sim 0.55,0.50, \sim 0.46$, respectively). These results indicate that FA shows a lower water demand than CSA cement at very early hydration times. This behavior would give the possibility of preparing blended pastes with FA at lower $\mathrm{w} / \mathrm{b}$ ratios, with the same viscosity than those without any FA addition, which may reduce the porosity of the cements and hence increase the compressive strength values of the corresponding mortars. Hence, these studies would allow the preparation of tailored pastes with specific viscosity by selecting both w/CSA or $\mathrm{w} / \mathrm{b}$ ratio and FA content.

Table 2 shows LoI and the theoretical total weight loss (calculated taken into account the added water and the LoI values for gypsum and FA) for all pastes at every studied hydration time. The comparison of these data were used, as quality control, to monitor that samples were properly stored as they were not dehydrated or taking too much extra water. Moreover, weight losses from $600{ }^{\circ} \mathrm{C}$ to $1000{ }^{\circ} \mathrm{C}$, from DTATGA measurements were also checked to verify potential carbonation process. These values are also included in Table 2 and it can be observed 
(a)

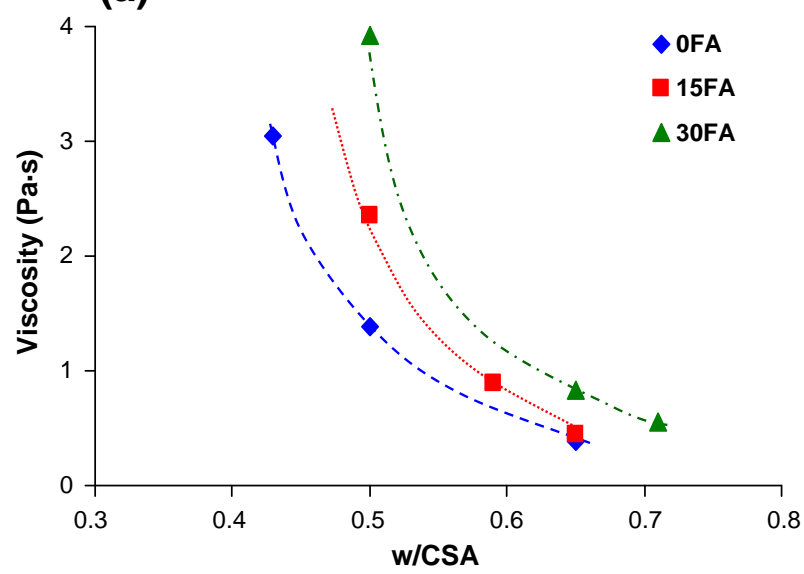

(b)

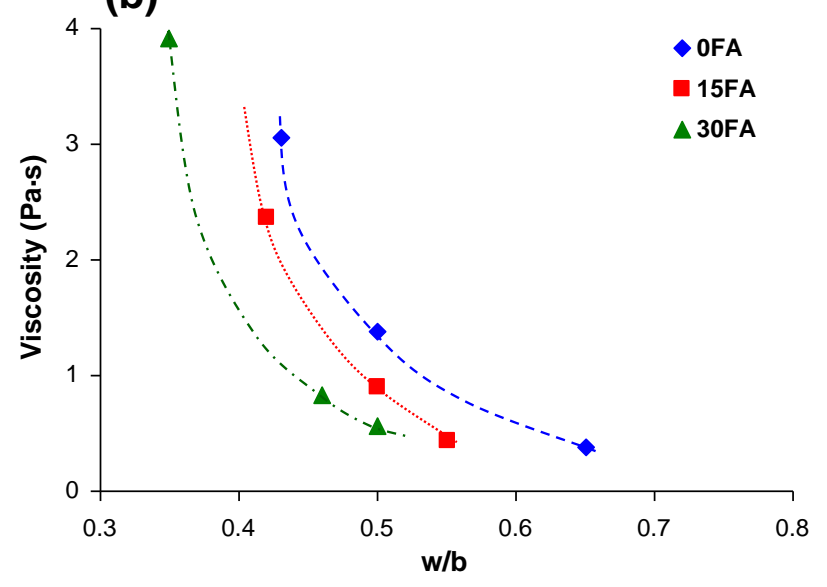

Fig. 2. Viscosity vs. w/CSA (a) and w/b (b) contents for all the pastes with different fly ash contents $(0,15$ and $30 \mathrm{wt} . \%)$ at the shear rate of $30 \mathrm{~s}^{-1}$ (values taken from the up-curve).

that, up to 28 days, carbonation process is negligible for all the studied pastes, and is appreciable at 180 days, mainly for high FA contents. Tables S1 to S8, deposited as supporting information, give the RQPA for all the studied samples as a function of time of hydration, including free water and ACn contents. It is worth highlighting that after 180 hydration days small amounts of free water still remains in the pastes, showing no drying effects. Small amounts of crystalline calcite and/or vaterite were identified and quantified at 180 days of hydration, confirming the small carbonation process that had carried out in the pastes. The free water content was determined by the difference between the experimental/added water and the combined water determined from TGA study (weight loss from RT to $600{ }^{\circ} \mathrm{C}$ ) and corrected from the LoI of CS10-25 (and FA if required). Table 2 also shows the expected water weight loss, up to $600{ }^{\circ} \mathrm{C}$, calculated by assuming fully inert FA and same hydration degree and chemical process than OFA paste (without fly ash). This calculation is useful to estimate/determine if FA has reacted. Comparing weight loss- $600{ }^{\circ} \mathrm{C}$ and expected weight loss $-600{ }^{\circ} \mathrm{C}$, Table 2 , it can be observed that experimental chemically bounded water contents are slightly larger than the expected ones (assuming inert FA). Although these values may be promising, the differences are not large enough to conclude that FA is reacting in these systems. The differences may be due to an increased reactivity due to the known 'filler effect' as the SCMs addition increases the surfaces for the hydration reaction(s).

Rietveld LXRPD study has been useful to follow the hydration process with time (see Tables S1 to S8 deposited as supporting information). As an example, Fig. 3a and b show the Rietveld plots for 15FA with $\mathrm{w} / \mathrm{CSA}=0.65$ pastes, after 3 and 180 days, respectively. The major peaks for a given phase are also labeled. Rietveld QPA results have been useful to follow $\mathrm{C}_{4} \mathrm{~A}_{3} \mathrm{~S}$ and $\mathrm{CSH}_{2}$ reactivity. At 3 days of hydration these two phases were dissolved at a large pace. Pore solution became oversaturated and high amounts of crystalline ettringite were present at all hydrating times, as expected, according to Eq. (1). Moreover, pore solution is known to be slightly oversaturated with respect to $\mathrm{AH}_{3}$, consequently this phase may precipitate [14]. Gibbsite $\left(\mathrm{AH}_{3}\right)$ is often reported [44] to be based on hydrous alumina using the term " $\mathrm{AH}_{3}$ " and it is considered as a poorly-crystallized or amorphous phase. In this study we confirm this finding and only a small fraction of the crystalline $\mathrm{AH}_{3}$ was identified by LXRPD, see Tables $\mathrm{S} 1$ to $\mathrm{S} 8$.

$\mathrm{C}_{4} \mathrm{~A}_{3} \underline{\mathrm{S}}+2 \mathrm{CS}_{\mathrm{S}}+34 \mathrm{H} \rightarrow \mathrm{C}_{6} \mathrm{AS}_{3} \mathrm{H}_{32}+2 \mathrm{AH}_{3}$

The chemical behavior of sulfates in these systems has been deeply studied through sulfate-containing phase dissolutions and crystallizations with time (normalized to $100 \mathrm{~g}$ of CSA cement for the sake of comparison). Fig. 4 shows the evolution of residual (res) sulfate, expressed as percentage of sulfate groups (after dissolution/reaction) and crystallized (cryst) sulfate for all the samples grouped according to w/CSA or $\mathrm{w} / \mathrm{b}$ ratios. The amount of reacted/dissolved sulfate was determined from the disappearance of ye'elimite and gypsum. This value was subtracted from the initial sulfate groups content to obtain the residual sulfate amount, Fig. 4. The amount of crystallized sulfate was determined from the appearance of ettringite and silicon-free AFm. The dotted lines in Fig. 4 indicate the maximum sulfate that can crystallize. The reactivity of sulfate-bearing phases slightly depends on the $w / C S A, w / b$ or FA addition, as pastes show very similar amounts of dissolved and crystallized sulfate groups, Fig. 4. However, the increase of w/CSA ratio from 0.50 to 0.65 has caused a higher dissolution degree, i.e. from $95 \%$ to close $100 \%$, respectively. Moreover, Fig. 4c clearly shows the slightly higher reactivity of ye'elimite and gypsum with the FA addition (which causes an increase in the w/CSA content for a fixed w/b). However, only a percentage of the dissolved sulfate is crystallized, an average of $40 \%$ of the total sulfate content may be in pore solution or $\mathrm{ACn}$ phase(s). The dissolved, but not crystallized, sulfate content values are much higher than those that can be in the pore solution [14], thus it must be inferred that a significant part of the sulfate content is included in the ACn fraction, as ill-crystallized AFm phases. Ettringite crystallization is slightly affected by the water content. It can be observed that in pastes with $\mathrm{w} / \mathrm{b}=0.50$, AFt crystallizes at a higher pace by increasing FA content, which implies higher w/CSA contents.

It is believed that sulfate anions in pore solution could be equilibrated by aluminum and calcium cations. $\mathrm{Fe}^{3+}$ cations are not evolved in these systems due to the lack of iron-bearing phases such as $\mathrm{C}_{4} \mathrm{AF}$. Hence, the chemical evolution of both aluminates ( $\mathrm{AlO}_{4}$ groups) as a source of aluminum cations and $\mathrm{Ca}^{2+}$ has been studied through dissolution and crystallization with time of phases containing these cations, as described above for sulfate groups. Figs. 5 and 6 show the evolution of residual aluminate and Ca groups, respectively, expressed as weight percent of both groups after dissolution/reaction and crystallization for all the samples grouped according to $\mathrm{w} / \mathrm{CSA}$ or $\mathrm{w} / \mathrm{b}$ ratios. Aluminate-res has been calculated taking into account the remaining $C_{4} A_{3} S$ content and aluminate-cryst from crystallized AFt, AFm and stratlingite, both expressed as percentage of aluminate groups. The dotted lines in Fig. 5 indicate the maximum aluminate that can crystallize, referred to the previously dissolved aluminate. Only a small percentage of the dissolved aluminate is crystallized (25-30\%), and thus $70-75 \%$ of the total aluminate content may be mainly as ACn phase(s). Due to the alkaline character of the pastes, $\mathrm{Al}^{3+}$ ions might well be forming $\mathrm{Al}(\mathrm{OH})_{3}$, which is mainly an ACn phase as explained before. On the other hand, calciumres stands for the calcium content obtained using the remaining gypsum, $C_{4} A_{3} S$ and $\beta-C_{2} S$ amounts and calcium-cryst stands for the calcium cation included in the crystallized $\mathrm{AFt}, \mathrm{AFm}$ and stratlingite, both 

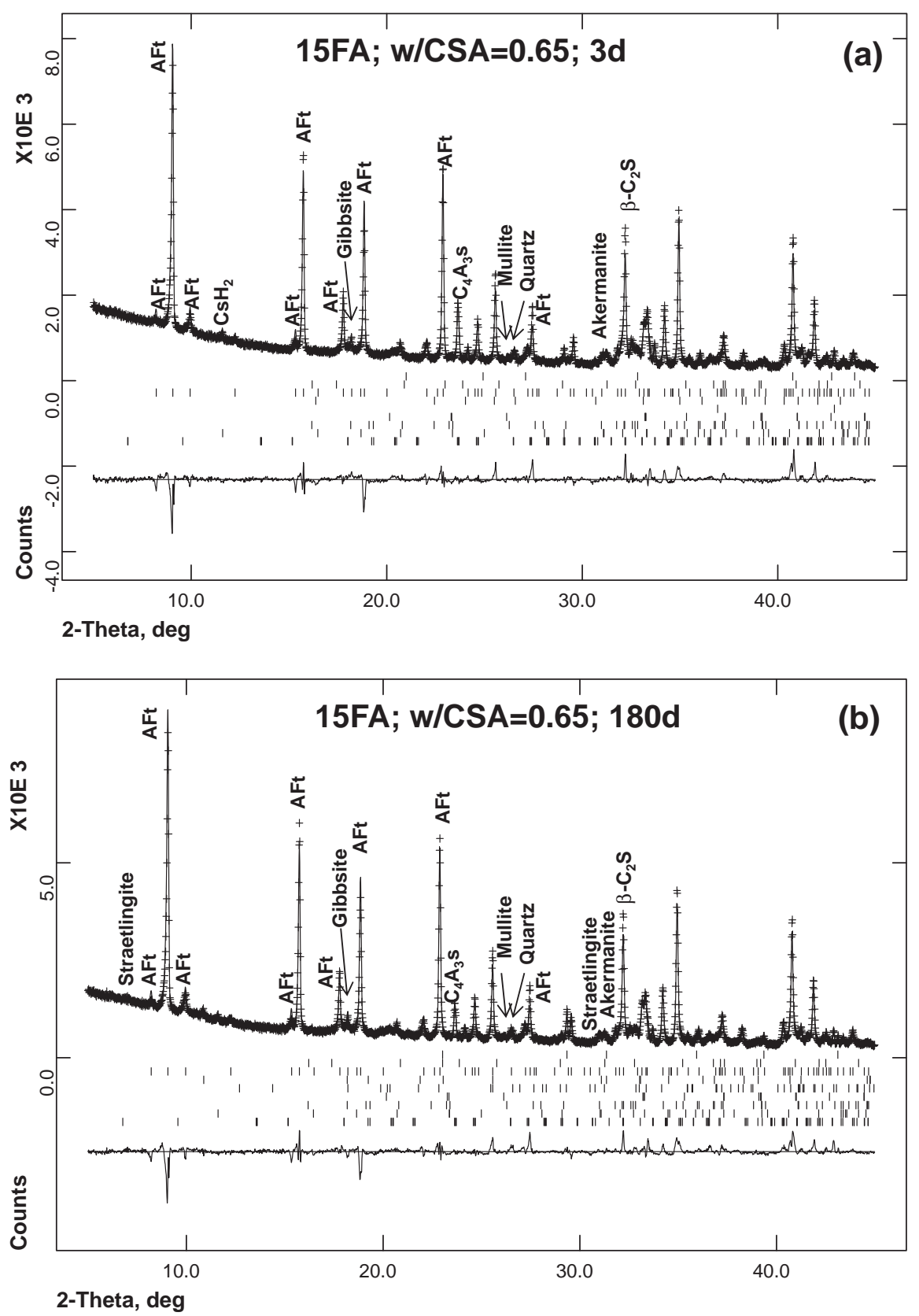

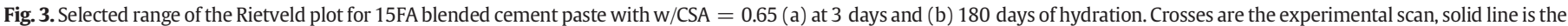
calculated pattern and the bottom line is the difference curve. The major peaks for each phase are labeled.

expressed as $\mathrm{Ca}^{2+}$ percentage. The dotted lines, as in previous figures, indicate the maximum $\mathrm{Ca}^{2+}$ that can crystallize referred to the previously dissolved calcium ions. $65 \%$ of the dissolved calcium is crystallized, and thus only a $35 \%$ of the total calcium content may be jointly with sulfate in the pore solution and as part of ACn phase(s), such as illcrystallized AFm. Moreover, the formation of an amorphous gel, similar to $\mathrm{C}-\mathrm{A}-\mathrm{S}-\mathrm{H}$ is not dismissed, although further research is required.

The hydration of $\beta-C_{2} S$ was also studied. The degree of hydration of belite is enhanced by increasing water addition. For instance, 30FA hydrated pastes with w/CSA of $0.50,0.65$ and 0.71 , the reaction degree of belite at 180 days is $18 \%, 45 \%$ and $49 \%$, respectively. These values were calculated taking into account the percentages of $\beta-\mathrm{C}_{2} \mathrm{~S}$ included in Tables S1 to S8. This phase, when is present in CSA cements, may react with water and $\mathrm{AH}_{3}$ to give stratlingite [14,16], Eq. (2). Some authors $[14,16]$ stated that this phase may precipitate after 28 days of hydration. However, in our studied pastes, this phase is only present in some pastes hydrated for 180 days. The main difference lies in the amount of $\beta-C_{2} S$, 19 wt.\% in [14] and more than 50 wt.\% in [16], compared to 9.4 wt.\% in this CSA clinker.

$\mathrm{C}_{2} \mathrm{~S}+\mathrm{AH}_{3}+5 \mathrm{H} \rightarrow \mathrm{C}_{2} \mathrm{ASH}_{8}$

Stratlingite was quantified using a revised crystal structural description which will be reported elsewhere. The first conclusion that can be extracted from Tables S1 to S8 is that stratlingite precipitation is strongly dependent to $\mathrm{w} / \mathrm{c}$ ratio. Small amounts of stratlingite are present in those pastes with high $\mathrm{w} / \mathrm{CSA}$ values: $\mathrm{w} / \mathrm{CSA}=0.65$ (OFA and 15FA), 15FA pastes with $\mathrm{w} / \mathrm{CSA}=0.59$ and 30FA pastes with $\mathrm{w} / \mathrm{CSA}=0.71$, while no stratlingite is present in those with $\mathrm{w} / \mathrm{CSA}=0.50$.

On the other hand, in cement pastes with $\mathrm{w} / \mathrm{CSA}=0.65$, the stratlingite measured at 180 days decreases from $1.1 \mathrm{wt} \%$ (OFA) to 0.4 wt.\% and 0.0 wt.\% by adding 15 and 30 wt.\% FA, respectively. This 

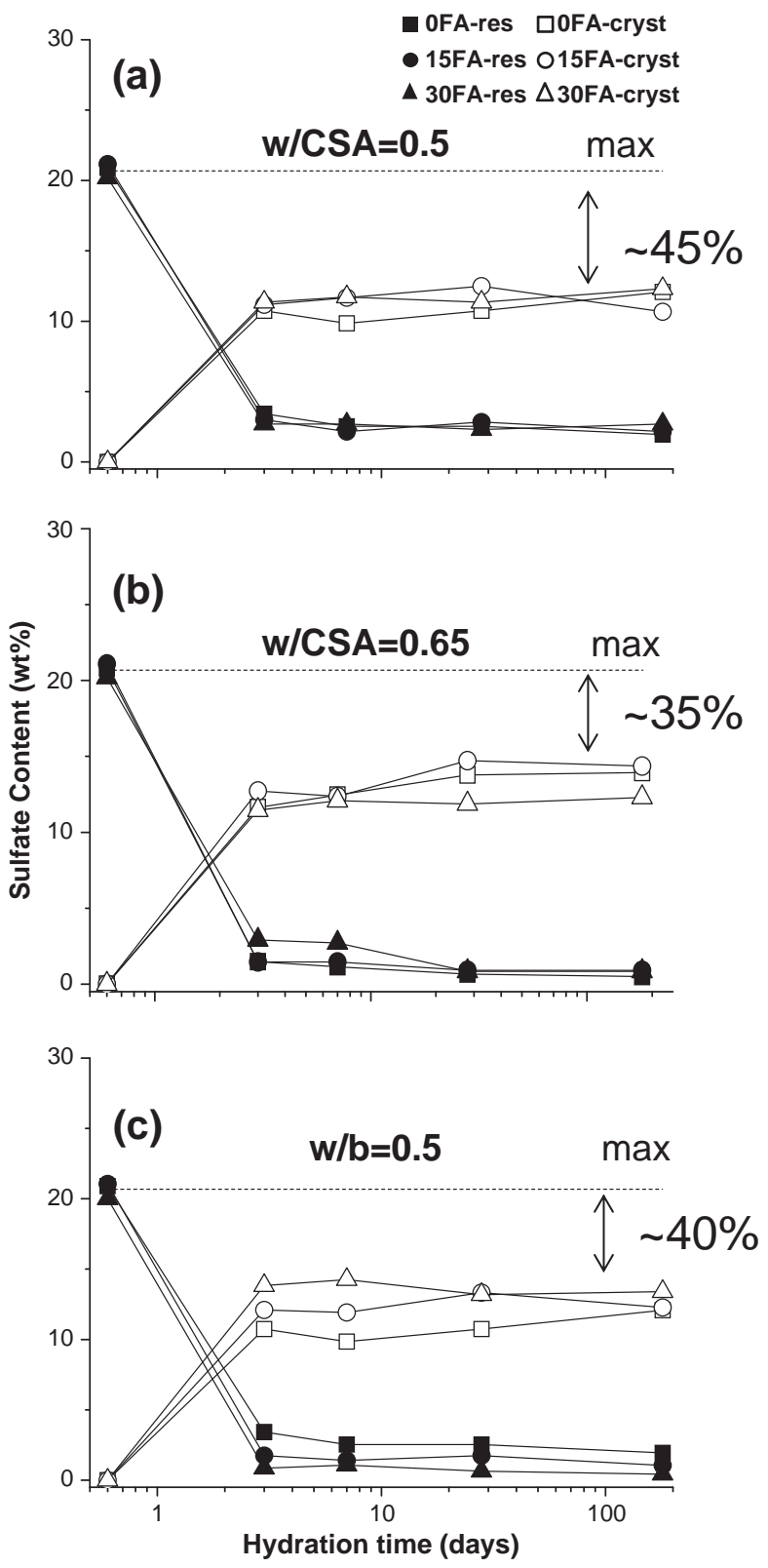

Fig. 4. Weight percentage of sulfate groups as a function of time, (a) $w / C S A=0.50$, (b) w/ $\mathrm{CSA}=0.65$ and $(\mathrm{c}) \mathrm{w} / \mathrm{b}=0.50$. XFA-res stands for the remaining gypsum and $\mathrm{C}_{4} \mathrm{~A}_{3} \mathrm{~S}$ contents and XFA-cryst stands for crystallized ettringite, both expressed as sulfate groups percentage.

result may indicate that $\mathrm{FA}$ is reacting with $\mathrm{AH}_{3}$, and thus this aluminum source is not longer available to react with $\mathrm{C}_{2} \mathrm{~S}$ to form stratlingite. However, these differences are too small to assure the FA reaction. Moreover, the amount of measured stratlingite contents are always much lower than those expected values taking into account the diminution of belite up to 180 days, in agreement to Winnefeld \& Lothenbach [14]. Therefore, we have to infer, that in these systems, belite is reacting mainly to give an amorphous phase likely a C-S-H type gel.

Moreover, the methodology used here is of direct applicability to study the hydration behavior of blended sulfobelite cements with fly ash (or related SCMs additions), where the belite contents are much higher. These studies are ongoing and they will be reported elsewhere.

Table 2 also shows the porosity values obtained by mercury porosimetry for all pastes at 7 and 180 days of hydration. Porosity decreases by increasing the hydration time and by decreasing the water
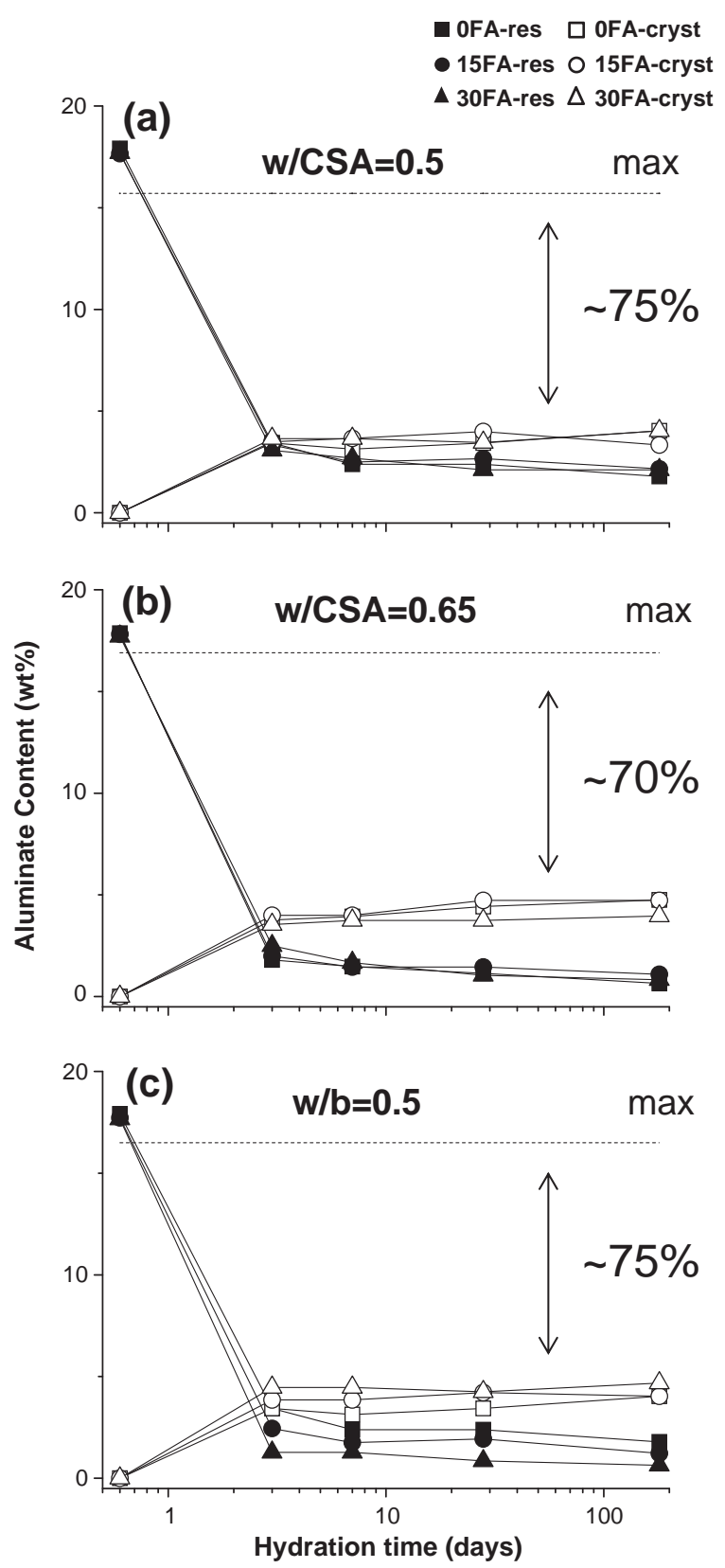

Fig. 5. Weight percentage of aluminate groups as a function of time, (a) $w / C S A=0.50$ (b) $\mathrm{w} / \mathrm{CSA}=0.65$ and $(\mathrm{c}) \mathrm{w} / \mathrm{b}=0.50$. XFA-res stands for the remaining $\mathrm{C}_{4} \mathrm{~A}_{3} \mathrm{~S}$ contents and XFA-cryst stands for crystallized AFt, AFm and stratlingite, both expressed as aluminate groups percentage.

content, as expected. Moreover, when fly ash is added to the pastes, the corresponding porosity values decrease mainly due to a filler effect. Finally the mechanical behavior of the corresponding mortars was studied. Fig. 7 gives the compressive strength values for mortars prepared from all pastes grouped according to their $\mathrm{w} / \mathrm{CSA}$ or $\mathrm{w} / \mathrm{b}$ ratios. They were carried out on small cubes as described in the experimental section. The influence of $\mathrm{w} / \mathrm{CSA}$ and FA/CSA ratios on the compressive strength development values is interrelated. Hence, a full study varying both parameters was carried out. From the analysis of the data it is clear that $\mathrm{w} / \mathrm{CSA}=0.50$ mortars always yield higher mechanical strengths than the analogous $\mathrm{w} / \mathrm{CSA}=0.65$ mortars, or $\mathrm{w} / \mathrm{b}=0.50$. These findings are in agreement with the porosity study. Furthermore, the role of FA content is also very important. The addition of fly ash affects in two different ways, firstly acts as a filler and secondly dilutes the 

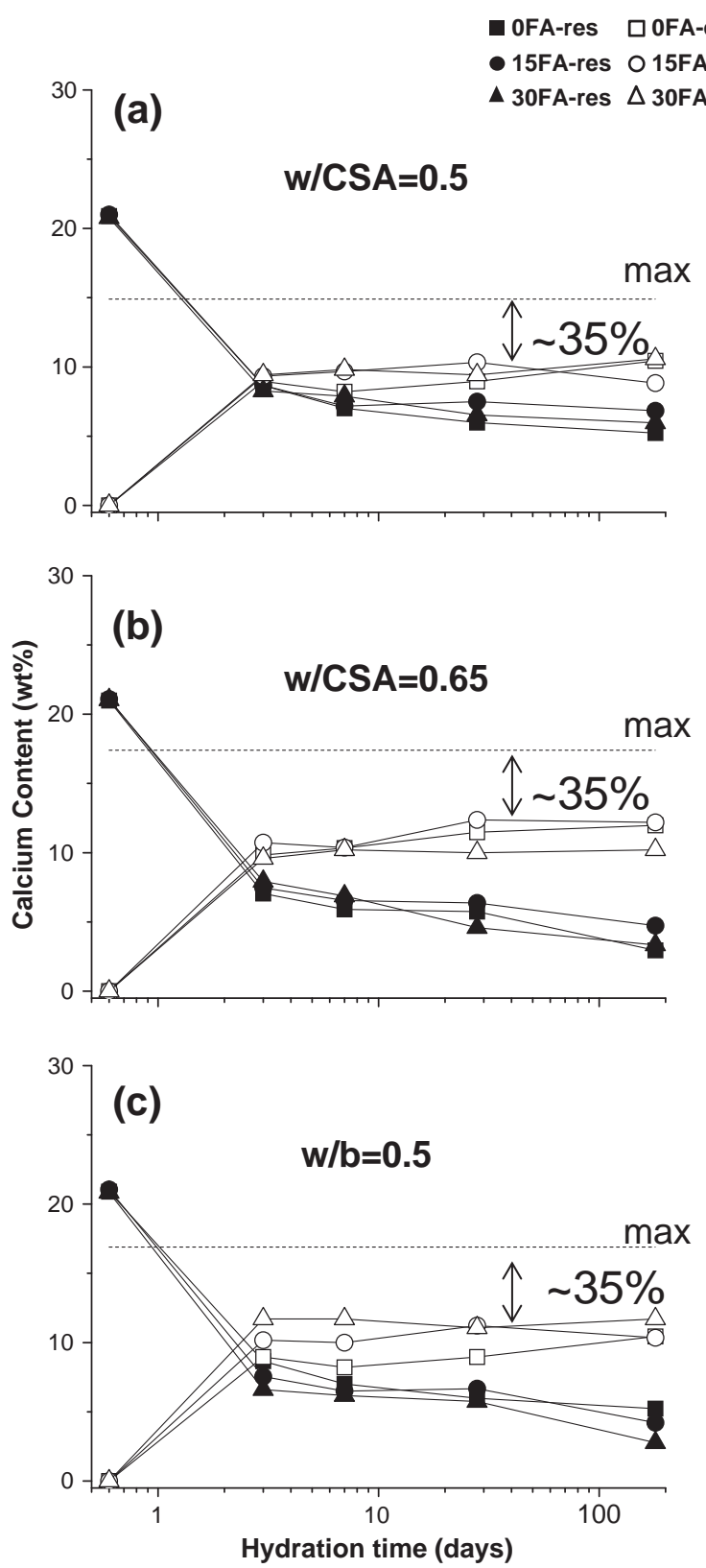

Fig. 6. Weight percentage of $\mathrm{Ca}^{2+}$ groups as a function of time, (a) $\mathrm{w} / \mathrm{CSA}=0.50$, (b) $\mathrm{w} / \mathrm{CSA}=0.65$ and $(\mathrm{c}) \mathrm{w} / \mathrm{b}=0.50$. XFA-res stands for the remaining gypsum, $\mathrm{C}_{4} \mathrm{~A}_{3} \mathrm{~S}$ and $\beta-C_{2} S$ contents and XFA-cryst stands for crystallized AFt, AFm and stratlingite, both expressed as $\mathrm{Ca}^{2+}$ percentage.

cement. On the one hand, the filler effect would increase the mechanical strengths of the corresponding mortars. In this way, cement pastes with 15 wt.\% of FA produce mortars with similar or slightly higher compressive strength values, Fig. 7a and b. In these mortars the filler effect has predominated over the cement dilution. On the other hand, the dilution produced by the addition of an excess of FA, i.e. $30 \mathrm{wt} . \%$, is not compensated by the filler effect, causing mortars with lower mechanical strength values, Fig. 7a and b. For a fixed w/b ratio, Fig. 7c, the dilution effect of the FA addition is exacerbated due to the higher $\mathrm{w} / \mathrm{CSA}$ ratios, and hence the filler effect is neglected, which causes mortars with lower mechanical strengths. These findings are strongly correlated with the porosity of the corresponding pastes, i.e. 7.8, 11.6 and 13.8 vol.\% for pastes with $\mathrm{w} / \mathrm{b}=0.50$ and 0,15 , and $30 \mathrm{wt} . \%$ of $\mathrm{FA}$, respectively, after 180 days, Table 2 .
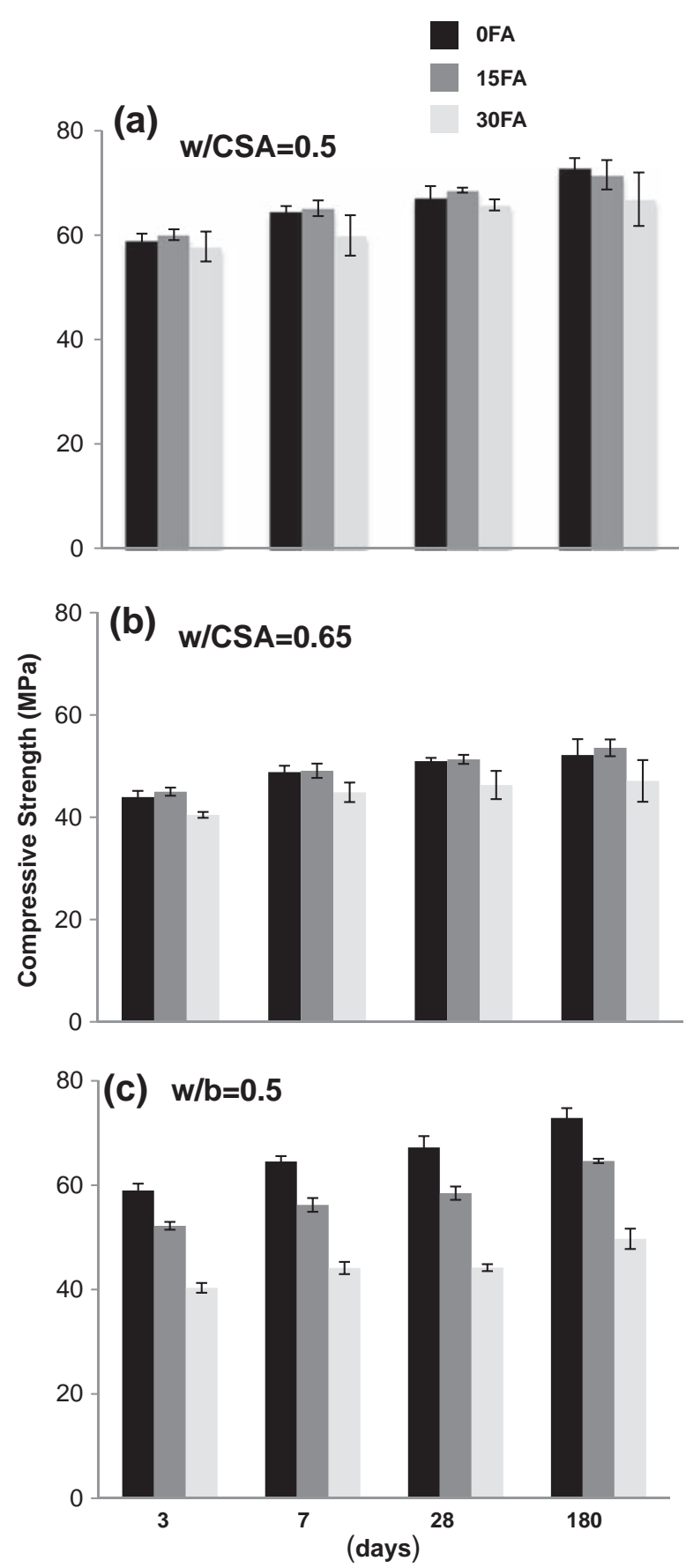

Fig. 7. Compressive strength values of mortars prepared from all pastes at different hydration times (3, 7, 28 and 180 days), (a) $w / C S A=0.50$, (b) $w / C S A=0.65$ and (c) $w / b=0.50$.

\section{Conclusions}

Hydration behavior of blended calcium sulfoaluminate cement pastes has been studied as a function of the added water and fly ash contents up to 6 months. All fresh pastes were rheologically characterized, where pastes blended with FA showed lower viscosity values (for the same $\mathrm{w} / \mathrm{b}$ ), hence lower water demands. The evolution of all pastes with time was studied through Rietveld quantitative phase analysis, thermal analysis, porosity and compressive strengths (mortars). $\mathrm{C}_{4} \mathrm{~A}_{3} \mathrm{~S}$ and gypsum were almost completely dissolved within the first three days of hydration where the main precipitating crystalline phase is ettringite (AFt). An average of $40 \mathrm{wt} \%$ of the total sulfate content of 
these pastes may be mainly part of the amorphous phases jointly with $70-75 \%$ of the total aluminate and $35 \%$ of the total calcium contents. ACn phases may be poorly crystallized AFm phases as well as gel-type phases with stoichiometries close to $\mathrm{AH}_{3}$ and $\mathrm{C}-\mathrm{A}-\mathrm{S}-\mathrm{H}$. Concerning belite reactivity, it has been proved that higher additions of water enhanced belite reactivity. Moreover, stratlingite is only precipitated at high w/CSA values and long hydration times (180 days). Thermal analysis and Rietveld QPA results are not strong enough to support the assumption of fly ash reactivity. Porosity decreases by increasing time, by decreasing water content, and with the addition of FA due to a filler effect, affecting mechanical strengths with the expected trend (the higher porosity the lower mechanical values). The partial substitution of CSA cement with fly ash has two main effects on the mechanical properties of the mortars: i) filler and ii) dilution effects. The former slightly increases compressive strengths of the corresponding mortars, as observed in mortars with 15 wt.\% of FA with w/CSA $=0.50$ or 0.65 . Contrarily, the latter predominates when 30 wt.\% of FA is added with negative effect in the mechanical strengths. For a fixed $\mathrm{w} / \mathrm{b}$ ratio, the mechanical properties of mortars decrease by increasing the amount of FA, mainly due to the higher water content, which causes higher porosity values. The partial substitution of cement by FA clearly involves economic and environmental benefits. Moreover, the chemical reactions during hydration in presence of FA do not change which suggests that durability is not compromised.

\section{Acknowledgments}

This work has been supported by Spanish MINECO through MAT2010-16213 research grant, which is co-funded by FEDER. I. Santacruz thanks a Ramón y Cajal fellowship, RYC-2008-03523.

\section{Appendix A. Supplementary data}

Supplementary data to this article can be found online at http://dx. doi.org/10.1016/j.cemconres.2013.07.010.

\section{References}

[1] M.A.G. Aranda, A.G. De la Torre, Sulfoaluminate cement, in: F. Pacheco-Torgal, S. Jalali, J. Labrincha, V.M. John (Eds.), Eco-efficient concrete, Woodhead Publishing Limited, Cambridge, 2013, pp. 488-522.

[2] E.M. Gartner, Industrially interesting approaches to "low- $\mathrm{CO}_{2}$ " cements, Cem. Concr. Res. 34 (2004) 1489-1498.

[3] J.H. Sharp, C.D. Lawrence, R. Yang, Calcium sulphoaluminate cements - low-energy cements, special cements or what? Adv. Cem. Res. 11 (1999) 3-13.

[4] C.D. Popescu, M. Muntean, J.H. Sharp, Industrial trial production of low energy belite cement, Cem. Concr. Compos. 25 (2003) 689-693.

[5] A. Feraille, A. Alaoui, A. Steckmeyer, R. Le Roy, New cements for sustainable development, Proceedings of the $12^{\text {th }}$ ICCC, Montreal, Canada, 2007.

[6] I. Odler, Special Inorganic Cements, Taylor and Francis Publisher, London, 2000.

[7] K. Quillin, Performance of belite-sulfoaluminate cements, Cem. Concr. Res. 31 (2001) 1341-1349.

[8] F.P. Glasser, L. Zhang, High-performance cement matrices based on calcium sulphoaluminate-belite compositions, Cem. Concr. Res. 31 (2001) 1881-1886.

[9] C. Cau dit Coumes, S. Courtois, S. Peysson, J. Ambroise, J. Péra, Calcium sulfoaluminate cement blended with OPC: a potential binder to encapsulate low-level radioactive slurries of complex chemistry, Cem. Concr. Res. 39 (2009) 740-747.

[10] Q. Zhou, N.B. Milestone, M. Hayes, An alternative to Portland cement for waste encapsulation - the calcium sulfoaluminate cement system, J. Hazard. Mater. 136 (2006) 120-129.

[11] J. Péra, J. Ambroise, New applications of calcium sulphoaluminate cement, Cem. Concr. Res. 34 (2004) 671-676.

[12] S. Sahu, J. Havlica, V. Tomková, J. Majling, Hydration behaviour of sulphoaluminate belite cement in the presence of various calcium sulphates, Thermochim. Acta 175 (1991) 45-52.

[13] M. Marchi, U. Costa, Influence of the calcium sulphate and $W / C$ ratio on the hydration of calcium sulphoaluminate cement, Proceedings of the $13^{\text {th }}$ International Congress on the Chemistry of Cement, Madrid, Spain, 2011.
[14] F. Winnefeld, B. Lothenbach, Hydration of calcium sulphoaluminate cements experimental findings and thermodynamic modelling, Cem. Concr. Res. 40 (2010) 1239-1247.

[15] G. Álvarez-Pinazo, A. Cuesta, M. García-Maté, I. Santacruz, E.R. Losilla, A.G. De la Torre, L. León-Reina, M.A.G. Aranda, Rietveld quantitative phase analysis of Ye'elimite-containing cements, Cem. Concr. Res. 42 (2012) 960-971.

[16] G.S. Li, G. Walenta, E.M. Gartner, Formation and hydration of low- $\mathrm{CO}_{2}$ cements based on belite, calcium sulfoaluminate and calcium aluminoferrite, Proceedings of the 12th ICCC, Montreal, Canada, 2007.

[17] B. Lothenbach, K.L. Scrivener, R.D. Hooton, Supplementary cementitious materials Cem. Concr. Res. 41 (2011) 1244-1246.

[18] E. Gartner, D.E. Macphee, A physico-chemical basis for novel cementitious binders, Cem. Concr. Res. 41 (2011) 736-749.

[19] R. Snellings, G. Mertens, J. Elsen, Supplementary cementitious materials, Rev. Mineral. Geochem. 74 (2012) 211-278.

[20] G.R. Quan, J. Shi, Y.L. Cao, Y.F. Xu, P.C. Chui, Properties of MSW fly ash-calcium sulfoaluminate cement matrix and stabilization/solidification on heavy metals, J. Hazard. Mater. 152 (2008) 196-203.

[21] V. Cívica, Properties of blended sulfoaluminate belite cement, Constr. Build. Mater 14 (2000) 433-437.

[22] S.R. Klaus, J. Neubauer, F. Goetz-Neunhoeffer, Hydration kinetics of $\mathrm{CA}_{2}$ and CA-Investigations performed on a synthetic calcium aluminate cement, Cem. Concr. Res. 43 (2013) 62-69.

[23] G. Le Saoût, B. Lothenbach, A. Hori, T. Higuchi, F. Winnefeld, Hydration of Portland cement with additions of calcium sulfoaluminates, Cem. Concr. Res. 43 (2013) 81-94.

[24] P. Termkhajornkit, T. Nawa, K. Kurumisawa, Effect of water curing conditions on the hydration degree and compressive strengths of fly ash-cement paste, Cem. Concr. Compos. 28 (2006) 781-789.

[25] K. De Weerdt, M. Ben Haha, G. Le Saoût, K.O. Kjellsen, H. Justnes, B. Lothenbach, Hydration mechanisms of ternary Portland cements containing limestone powder and fly ash, Cem. Concr. Res. 41 (2011) 279-291.

[26] M. García-Maté, I. Santacruz, A.G. De la Torre, L. León-Reina, M.A.G. Aranda, Rheological and hydration characterization of calcium sulfoaluminate cement pastes, Cem. Concr. Compos. 34 (2012) 684-691.

[27] G. Bernardo, A. Telesca, G.L. Valenti, A porosimetric study of calcium sulfoaluminate cement pastes cured at early ages, Cem. Concr. Compos. 36 (2006) 1042-1047.

[28] I.A. Chen, C.W. Hargis, M.C.G. Juenger, Understanding expansion in calcium sulfoaluminate-belite cements, Cem. Concr. Res. 42 (2012) 51-60.

[29] J. Ambroise, J.F. Georgin, S. Peysson, J. Péra, Influence of polyether polyol on the hydration and engineering properties of calcium sulphoaluminate cement, Cem. Concr. Compos. 31 (2009) 474-482.

[30] W. Chang, H. Li, M. Wei, Z. Zhu, J. Zhang, M. Pei, Effects of polycarboxylic acid based superplasticizer on properties of sulphoaluminate cement, Mater. Res. Innov. 13 (2009) 7-10.

[31] A. Fernández-Jiménez, M. Monzó, M. Vicent, A. Barba, A. Palomo, Alkaline activation of metakaolin-fly ash mixtures: obtain of zeoceramics and zeocements, Microporous Mesoporous Mater. 108 (2008) 41-49.

[32] J. Wang, Hydration mechanism of cements based on low- $\mathrm{CO}_{2}$ clinkers containing belite, ye'elimite and calcium alumino-ferrite. PhD Thesis University of Lille, France, 2010

[33] D. Jansen, F. Goetz-Neunhoeffer, C.H. Stabler, J. Neubauer, A remastered external standard method applied to the quantification of early OPC hydration, Cem. Concr. Res. 41 (2011) 602-608.

[34] J.P. Cline, R.B. Von Dreele, R. Winburn, P.W. Stephens, J.J. Filliben, Addressing the amorphous content issue in quantitative phase analysis: the certification of NIST standard reference material 676a, Acta Crystallogr. A 67 (2011) 357-367.

[35] A.C. Larson, R.B. Von Dreele, General structure analysis system (GSAS), Los Alamos National Laboratory Report LAUR, 2000. 86-748.

[36] P. Thompson, D.E. Cox, J.B. Hasting, Rietveld refinement of Debye-Scherrer synchrotron X-ray data from $\mathrm{Al}_{2} \mathrm{O}_{3}$, J. Appl. Crystallogr. 20 (1987) 79-83.

[37] L.W. Finger, D.E. Cox, A.P. Jephcoat, A correction for powder diffraction peak asymmetry due to diaxial divergence, J. Appl. Crystallogr. 27 (1994) 892-900.

[38] M.A.G. Aranda, A.G. De la Torre, L. León-Reina, Rietveld quantitative phase analysis of OPC clinkers, cements and hydration products, Rev. Mineral. Geochem. 74 (2012) 169-209.

[39] B.H. O'Connor, M.D. Raven, Application of the Rietveld refinement procedure in assaying powdered mixtures, Powder Diffract. 3 (1998) 2-6.

[40] D. Jansen, C.H. Stabler, F. Goetz-Neunhoeffer, S. Dittrich, J. Neubauer, Does ordinary Portland cement contain amorphous phase? A quantitative study using an external standard method, Powder Diffract. 26 (2011) 31-38.

[41] P.M. Suherman, A.V. Riessen, B. O'Connor, D. Li, D. Bolton, H. Fairhurst, Determination of amorphous phase levels in Portland cement clinker, Powder Diffract. 17 (2002) 178-185.

[42] P.S. Whitfield, L.D. Mitchell, Quantitative Rietveld analysis of the amorphous content in cements and clinkers, J. Mater. Sci. 38 (2003) 4415-4421.

[43] A. Cuesta, A.G. De la Torre, E.R. Losilla, V.K. Peterson, P. Rejmak, A. Ayuela, C. Frontera, M.A.G. Aranda, Structure, atomistic simulations, and phase transition of stoichiometric yeelimite, Chem. Mater. 25 (2013) 1680-1687.

[44] K.L. Scrivener, A. Capmas, Calcium aluminate cements, in: P.C. Hewlett (Ed.), Lea's Chemistry of Cement and Concrete, Elsevier Ltd, 2003, pp. 713-782. 